ENTREPRENEURSHIP AND SUSTAINABILITY ISSUES

ISSN 2345-0282 (online) http://jssidoi.org/jesi/

2021 Volume 8 Number 4 (June)

http://doi.org/10.9770/jesi.2021.8.4(43)
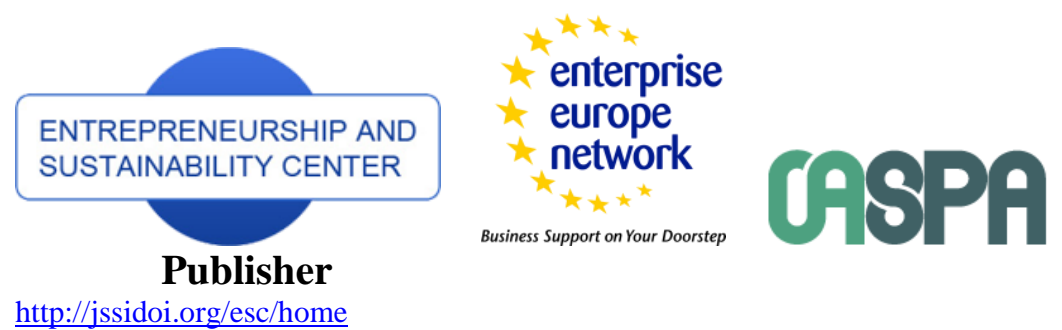

Business Support on Your Doorstep

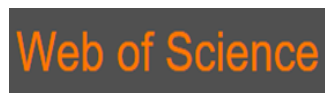

$\underline{\text { http://jssidoi.org/esc/home }}$

\title{
ENTREPRENEURIAL ACTIVITY OF THE IT SECTOR IN THE CONDITIONS OF THE COVID-19 PANDEMIC AND IN THE POST-QUARANTINE PERIOD
}

\author{
Vladislav Fedorenko ${ }^{1 *}$, Natalia Filipenko ${ }^{2}$, Inesa Shumilo ${ }^{3}$, Volodymyr Nesterovych ${ }^{4}$, \\ Svitlana Nischymna ${ }^{5}$ \\ ${ }^{1 *}$ Research Center for Forensic Examination on Intellectual Property of the Ministry of Justice of Ukraine, 26, L. Ukrainka \\ Boulevard, office 501, Kyiv, 01133, Ukraine \\ ${ }^{2}$ Zhukovsky National Aerospace University "Kharkiv Aviation Institute", Chkalova Street, 17, Kharkiv, 61000, Ukraine \\ ${ }^{3}$ Yaroslav Mudryi National Law University, 77 Pushkinskaya Street, Kharkiv, 61024, Ukraine \\ ${ }^{4}$ Lugansk State University of Internal Affairs named after E.O. Didorenko, Donetsk Str., 1, Severodonetsk, 93400, Ukraine \\ ${ }^{5}$ Academy of the State Penitentiary Service, Honcha str. 34, Chernihiv, 14000, Ukraine \\ E-mails: ${ }^{1 *}$ fedorenko@ukr.net (Corresponding author)
}

Received 25 February 2021; accepted 8 May 2021; published 30 June 2021

\begin{abstract}
Despite the rapid growth rate, the IT sector of Ukraine is characterized by a weak competitive position due to work in the lowcost segment and growing competition from companies located in low-income countries; mainly outsourcing model of IT business development, which is determined by a low level of margins. This model of development of the IT sector of Ukraine is due, in particular, to the low efficiency of competitiveness management technologies used by IT companies. The latter actualizes the development of adequate mechanisms for managing the competitiveness of companies in the IT sector of Ukraine. The purpose of the paper is to develop the theory and procedural guidelines for the formation of assessment and forecasting of the level of competitiveness of companies in the IT sector. The works in the field of cognitive management, cognitive control, adaptive management, proactive management, competitiveness management are the theoretical-methodological basis of the paper. The assessment and forecasting of the state of the environment of 20 IT companies of Ukraine were carried out, the inertial scenario of their development was created, and forecasting of threats to sustainable operation of the companies was carried out. Comparison of the current and forecast level of competitiveness allowed to assess the stability of competitive positions of the companies, to identify the IT companies, for which it is advisable to develop proactive strategies aimed at reversing the negative trends, which are formed according to forecast data on the accepted competitiveness management strategy. It was demonstrated that the negative consequences of the "shock" of COVID-19 (in particular, 61 of the 68 largest companies in the IT sector (90 \%) included in the S \& P500 index are characterized by negative market value dynamics) lead to the need to consider adaptive strategy as a focus strategy.
\end{abstract}

Keywords: money laundering; shadow economy; business activity; stability; risk

Reference to this paper should be made as follows: Fedorenko, V., Filipenko, N., Shumilo, I., Nesterovych, V., Nischymna, S. 2021. Entrepreneurial activity of the IT sector in the conditions of the COVID-19 pandemic and in the post-quarantine period. Entrepreneurship and Sustainability Issues, 8(4), 697-712. http://doi.org/10.9770/jesi.2021.8.4(43)

JEL Classifications: K22, L21 


\section{ENTREPRENEURSHIP AND SUSTAINABILITY ISSUES}

ISSN 2345-0282 (online) http://jssidoi.org/jesi/

2021 Volume 8 Number 4 (June)

http://doi.org/10.9770/jesi.2021.8.4(43)

\section{Introduction}

Maintaining quarantine restrictions on certain types of economic activity against the background of the general trend of economic stagnation led to critical risks for national entrepreneurship. The sharp decline in the activities of small and medium-sized enterprises (hereinafter - SMEs) in Ukraine can have devastating systemic consequences for the national economy leading to: declining GDP and deteriorating macroeconomic imbalances, destabilization of the banking system due to defaults of business entities and individuals-borrowers who lost their jobs, growing unemployment, increasing receivables and payables. Quarantine measures have exacerbated the problems of uneven impact of quarantine on certain segments of entrepreneurship at the national and local levels, i.e., micro and small businesses have suffered more, which makes actual the task of setting priorities for SME support.

The "cascade" model of the crisis is typical for the current stage of the economic development of Ukraine. Thus, in the crisis periods of development, the decrease in GDP was $16.4 \%$, and in the periods of economic recovery it increased only by $11.5 \%$. Experts predict that this model of crisis may be repeated in the future. In particular, the economic "shock" of the COVID-19 pandemic could have similar consequences: the rate of recovery of economic activity in Ukraine may be much slower than in other countries, such as countries close to the level of economic development of the Eastern European bloc.

Crisis trends in economic development lead to negative changes in the social sphere: tax revenues are reduced, the budget deficit is growing, social protection programs are reduced, social tensions are growing, the share of the population living below the poverty line is increasing, the intensity of migration trends is increasing.

The current situation brings to the fore the implementation of an effective economic recovery strategy announced by the Ministry of Economic Development, Trade and Agriculture in February 2020 (National Economic Strategy 2030 (2021)). Within the framework of the announced strategy there were identified sectoral priorities aimed at forming economic zones of outpacing growth, development of sectors that generate impetus for cluster development of related industries and ensure effective integration of the domestic production and economic system into global value chains.

The development of the IT sector was determined as one of such sectoral priorities. According to experts, it is this sector that has the highest level of competitiveness, level of innovation of the used technologies and skills. The IT sector accounts for 4\% of GDP, a significant share of newly created jobs (National Accounts (GDP) (2020)). According to the NASSCOM association, the attraction of one programmer in the sector leads to the creation of 4 jobs in related industries (Essential Information. NASSCOM (2021)).

\section{Literature review}

A number of leading countries are implementing large-scale national business support programs to minimize the effects of quarantine restrictions, to improve liquidity, minimize the effects of supply chain disruptions, providing tax benefits and vacations, business cash subsidies, lower interest rates and implementation of credit programs.

Thus, according to IMF estimates (IMF Digest of the COVID-19 Response Policy (2021)), Poland provided for the provision of credit guarantees and microcredit for entrepreneurs in the amount of PLN 75 bln (3.3\% of GDP in 2019), Romania - through the provision of initial guarantees of $10 \mathrm{bln}$ lei (1\% of GDP) for guarantees on loans and subsidized interest for working capital and investments of SMEs; Estonia provides loans to rural companies through the Agricultural Development Fund ( $€ 200 \mathrm{mln}$ ), guarantees secured by bank loans to reschedule payments $(€ 1 \mathrm{bln})$, business loans to support company liquidity ( $€ 500 \mathrm{mln})$, investment loans to 


\section{ENTREPRENEURSHIP AND SUSTAINABILITY ISSUES}

ISSN 2345-0282 (online) http://jssidoi.org/jesi/

2021 Volume 8 Number 4 (June)

http://doi.org/10.9770/jesi.2021.8.4(43)

companies ( $€ 50 \mathrm{mln})$; the United Kingdom allocates $£ 27$ bln in small business grants to affected sectors, launch of Coronavirus Affected Business Lending program to support SMEs; Italy implements measures to support credit proposals (€5.1 bln); Germany allocated $€ 50$ bln in subsidies to small businesses and the self-employed, expanding and accessing government loan guarantees for firms, allocating at least $€ 822$ bln for these purposes (24\% of GDP).

In general, the governments of many countries have directed significant public funding to support the economy, in particular: Estonia — € $€$ bln (7 \% of GDP), Latvia — €1 bln (3\% of GDP), Lithuania - $€ 2.5$ bln (5\% of GDP), and Italy - $€ 25$ bln ( $1.4 \%$ of GDP). In China, Germany and the USA there have been approved and implemented measures on health care, sick lists, small business loans and international assistance amounting to $1.2 \%$ of GDP ( 1.3 trillion yuans), $4.5 \%$ of GDP ( $€ 156 \mathrm{bln})$ and $0.5 \%$ of GDP, respectively. An additional USD 2 trillion is expected to be allocated (about $10 \%$ of GDP). For Ukraine, expenditures to combat COVID-19 are incomparably lower (Operational information on expenditures to combat COVID-19 (2021)) and amount to UAH $1.972 \mathrm{bln}$ and are related to much smaller financial and economic opportunities of the national economy.

A study of the activities of SMEs in quarantine has identified such risks:

- Cessation of business. According to the Info Sapiens survey (60\% of Ukrainians have suffered financial losses due to the coronavirus pandemic (2020)), only $66 \%$ of SMEs will be able to diversify their activities, unlike companies in highly specialized segments, which will be forced to cease operations. The largest negative impact is experienced by industry, wholesale and retail trade and agriculture, which create $44 \%$ of value added and provide $55 \%$ of jobs (60\% of Ukrainians have suffered financial losses due to the coronavirus pandemic (2020)). Although the hotel and restaurant business has a small share (1\%) in the economy structure, $60 \%$ of it are small enterprises, which need support in the first place.

- Liquidity deficit. The presence of cash gaps and the lack of sufficient savings do not allow many SMEs to cover fixed operating costs in the case of suspension of operations. The possibility of cessation of business through quarantine is considered by 3 to $10 \%$ of SMEs (60\% of Ukrainians have suffered financial losses due to the coronavirus pandemic (2020)).

- Large-scale reduction and narrowing of the structure of consumer demand. Reducing the demand for nonessential goods/services will dramatically affect the decline in revenues of enterprises in other areas of activity. $62 \%$ of the population have negative consumer expectations (60\% of Ukrainians have suffered financial losses due to the coronavirus pandemic (2020)).

- Disruption of the value and supply chains. Well-established business processes, namely buying/logistics/sales are disrupted during quarantine activities, and due to the shutdown of some partners, SMEs are forced to resume operations by way of search for new alternative markets for raw material supply and service outsourcing (Maritz et. al (2020)).

- Loss of the domestic sales market. Decreasing incomes of the population during the quarantine period will reduce the domestic market (Battaglia et. al (2021)). Currently, there is no effective compensation mechanism, which can effectively restore the business activities, and representatives of the segment can not predict either the period of the crisis or the tools to overcome it (Leach et. al (2021)).

- Uncertainty in foreign markets, primarily regarding post-quarantine volumes, terms and opportunities for export recovery (Ketchen \& Craighead (2020)).

\section{Research Methodology and Data}

The scientific works in the field of cognitive management, cognitive control, adaptive management, proactive management, competitiveness management are the theoretical-methodological basis of the paper. To solve the tasks set in the paper there were used both general scientific research methods such as logical-theoretical generalization, analysis, synthesis, and special ones such as the methods of expert analysis, methods of analysis of panel data, scenario modeling. 


\section{ENTREPRENEURSHIP AND SUSTAINABILITY ISSUES}

ISSN 2345-0282 (online) http://jssidoi.org/jesi/

2021 Volume 8 Number 4 (June)

http://doi.org/10.9770/jesi.2021.8.4(43)

The combined use of machine learning methods, expert analysis, panel data analysis methods allowed to solve the problem of developing a methodical approach to assessing the stability of competitive positions of IT enterprises. The information base of the study is the data of such professional public organizations as Kharkiv IT Cluster, Lviv IT Cluster, Kyiv IT Cluster, IT Ukraine Association, statistics of the State Statistics Service of Ukraine, reports of the Ministry of Finance of Ukraine, data of global and national information-analytical platforms, financial reports of IT companies, and expert assessments. The proposed approach to assessing and forecasting the level of competitiveness is tested on the data of 20 companies in the IT sector of Ukraine. The information base of the paper is the data of information-analytical portals and financial reports of IT companies for 20152019.

The above methodical approach to assessing and forecasting the level of competitiveness is tested on the data of 20 companies in the IT sector of Ukraine. The information base of the paper is the data of information-analytical portals and financial reports of IT companies for 2015-2019.

The purpose of the paper is to develop the theory and procedural guidelines for the formation of assessment and forecasting of the level of competitiveness of companies in the IT sector.

\section{Results}

The "post-virus world" as a global environment in which business will exist in the medium term will change, which will give rise to new priorities of business strategies due to the emergence of such trends.

Appearance of new sales channels. In order to reduce the negative pressure of quarantine barriers to normal economic activity, companies should develop alternative sales channels. We are talking about the sale of traditional products and services through online channels by digitizing business processes for the sale of products/services, or by using intermediary platforms. With the formation of new digital platforms, companies should shift sales efforts in B2C and B2B market segments to new channels. Going online will be a strategy for quick results.

Use of existing industrial facilities for the production of new goods. COVID-19 reduced demand for certain groups of goods and services, which led to underutilization of organizational-industrial infrastructure. At the same time, demand for other groups of goods remains high or grows asymmetrically. It is advisable to refocus the underutilized infrastructure for the production of goods and services to combat COVID-19, as well as to meet future changes in consumer demand.

Rapid introduction of innovations around new needs. In addition to balancing the product range, new customer needs create opportunities for innovation. In the face of crisis threats or significant changes in market structure, in addition to safeguards, companies need to focus on innovation that enables them to reap the benefits of emerging opportunities. It is important to inform about the Internet offers of companies and improve digital customer loyalty.

Development of industrial capacity to meet expanded demand. For companies from growing segments, it is advisable to expand their infrastructure to increase production capacity. The development of partnerships with other companies can increase industrial and logistics capacity in a crisis. To meet the needs in new infrastructure, it is advisable to cooperate with external partners in the framework of the sharing economy.

Constant focus on identifying new consumption habits that are being formed. Changes in consumption patterns caused by the coronavirus pandemic will continue in the post-quarantine period. Most sectors are refocusing on 


\section{ENTREPRENEURSHIP AND SUSTAINABILITY ISSUES}

ISSN 2345-0282 (online) http://jssidoi.org/jesi/

2021 Volume 8 Number 4 (June)

http://doi.org/10.9770/jesi.2021.8.4(43)

new market realities in many countries around the world. It is difficult to determine which new habits will persist in the long run, but significant opportunities include moving from offline to online education, transforming health care, and increasing the use of digital sales channels. Companies must accelerate digital transformation, development of digital marketing tools, building partnerships through Internet platforms.

Using social networks to coordinate the activities of employees and partners. Thanks to remote work and a new set of coordination problems, companies are aware of the need to use social networks to coordinate the actions of employees and partners. A separate area is the initiation by companies of training and motivation of personnel to promote the products of a company on social networks.

Search for new sources of income. Following the end of the coronavirus pandemic, there is a high probability that many markets will shrink and demand will remain low on the part of consumers and businesses for a long time. As competition intensifies, search for new revenue opportunities will be critical to the sustainability of companies. Although specific strategies will depend on areas of activity or markets, new opportunities for all activities are created by building ecosystems that focus on partnerships, product innovation, development of digital channels (marketing, sales of products, learning about changing preferences and habits, etc.). To take on new markets, companies in both the manufacturing and services sectors need to develop products that reflect current needs.

Improving the level of training, skills and qualifications of the workforce in accordance with the needs of the new world. Restrictions on economic activity during the coronavirus pandemic forced all companies to reconsider almost every aspect of their activities: remote work, digital interaction/use of new technologies. This places before a company a challenge of ensuring that personnel acquire the necessary skills and increase their readiness to accept change. The speed of technological progress has created significant demands for training of the workforce, and post-crisis requirements will increase this need. In addition to the technical training of employees, it is necessary to carefully assess the skills and competencies that need to be focused on, invest in training and assess the impact of changes on the activities of a company. This will allow to increase productivity, support innovation, increase the sense of involvement of employees and their job satisfaction.

Given the cessation of a number of economic processes and weakening domestic demand related to measures to combat the COVID-19 pandemic, the priorities of support and development of SMEs in Ukraine should be identified.

Radical reduction of government intervention in the activities of economic entities, elimination of administrative barriers to doing business. Constant changes in legislation on SMEs, which establish new rules and requirements for micro, small and medium-sized businesses, affect the institutional weakness of SMEs, ignorance of how to act in accordance with the law, and create grounds for claims by state supervisory and control bodies. According to the State Regulatory Service of Ukraine (SRSU) (SRSU will continue to work on elimination of legal, administrative, economic and organizational barriers to business (2020)), in 2019 the introduction of state regulations was prevented, which provided for almost UAH 33.1 bln additional costs for business entities, by deciding to refuse to approve the relevant draft regulations (in 2018 - UAH $43.5 \mathrm{bln}$ ).

Systemic reduction of corruption. Insufficient integrity of separate officials, abuse of power, lack of critical attitude of business representatives to corruption and illegal material incentives as a tool to address issues, contribute to corruption and complicate its eradication. Some local government officials do not always properly perform the powers delegated to them, which creates grounds for corruption, and some actions of local government officials are seen as pressure on business. According to the corruption indicator in the "Report on the assessment of the implementation of state policy for the development of small and medium-sized enterprises in Ukraine, USAID CEU 2019", $44.6 \%$ of SMEs considered corruption to be the main obstacle to doing business 


\section{ENTREPRENEURSHIP AND SUSTAINABILITY ISSUES}

ISSN 2345-0282 (online) http://jssidoi.org/jesi/

2021 Volume 8 Number 4 (June)

http://doi.org/10.9770/jesi.2021.8.4(43)

(the program USAID Competitive Economy of Ukraine (CEU) receives concepts of grant projects from business associations (APS) (2021)).

Modernization of the tax system based on the introduction of rational tax innovations (replace the corporate income tax with withdrawn capital tax; expand the list of excisable goods in accordance with EU Directives), simplify tax administration, timely refund VAT and reduce the burden on the payroll by reducing the rates of single social security tax or reducing the personal income tax rate.

Improving access of SMEs to financing in the banking and non-banking sectors through simplification of borrowing and collateral requirements. SMEs require increasing the volume of financing through existing and new programs to replenish working capital, including for payment of labor/rent with a grace period of debt service of at least 60 days. SMEs that have lost more than $15 \%$ of their sales require a special approach to determining the amount of interest on loans (or compensation from the state) and the ability to obtain loans without collateral. Free access to lending also provides simple procedures for obtaining a loan, including the speed of its obtaining (up to 48 hours from the date of request) using online access.

Expansion of capabilities, foreign economic activity of SMEs. The high level of uncertainty regarding the volume, terms and patterns of export recovery is related to the lack of long-term contracts for large amounts, so the risk of losing export potential increases (approximately $30 \%$ of exports of Ukraine). In the face of new challenges, SMEs have partially lost the chains of international cooperation, which has affected their competitiveness in international markets, increased the need to preserve existing trading partners and find new markets. This is exacerbated by the lack of export credit and the lack of knowledge and skills to find partners through the placement of information on the proposals of a company in EEN (Helping companies innovate and grow internationally (2021)).

Increasing the level of digitalization of public services and entrepreneurial competencies of SMEs, increasing the volume of e-commerce. In the conditions of quarantine restrictions, impossibility of offline work of many areas of activity of SMEs and cooperation with authorities, there is a choice between business closure and its adaptation to new conditions through development of tools of remote online access (expansion of the list of public services, ecommerce development). Government support is required to effectively adapt to the forced wave of digitization (only $66 \%$ have the opportunity of digitalization or repurposing), which depends on Internet coverage and the availability of specialized knowledge and competencies. State aid should be focused primarily on stimulating the introduction of remote business processes, as well as the use of digital tools to find new alternative markets. SMEs should systematically expand data analysis and information flow management tools.

The negative consequences of the "shock" of COVID-19 (in particular, 61 of the 68 largest companies in the IT sector $(90 \%)$ included in the S \& P500 index (S\&P500 (2020)) are characterized by negative market value dynamics) lead to the need to consider proactive adaptive strategy as a focus strategy in the cognitive competitiveness management of an IT company. The priority of the latter is explained by the fact that it allows to predict crisis processes in the early stages of their development before the moment of losses and damages. It is aimed at anticipating certain areas of industry development, allows to develop adequate preventive management decisions, which localize disturbances, prevent or minimize losses, to ensure a stable trajectory of the development of a company by increasing the speed of adaptive response and, as a consequence, to maintain a high level of competitiveness and business value.

Two requirements were taken into account when forming the system of diagnostic indicators of competitiveness of IT companies: high or average values of the probability of dominance of indicators reflecting the importance of indicators for the assessment of competitiveness $(\mathrm{KC})$ from the point of view of experts, and the availability of 
information on the indicators in open databases. The developed system of diagnostic indicators is given in Table 1.

Table 1. System of diagnostic indicators of competitiveness of an IT company

\begin{tabular}{|c|c|c|}
\hline No. & Indicator group (area of evaluation) & Indicator (symbol) \\
\hline 1 & Market activity level & $\begin{array}{l}\text { Number of structural divisions of a company }\left(x_{1}\right) \text {, number of industry solutions } \\
\text { (areas of activity) }\left(x_{2}\right)\end{array}$ \\
\hline 2 & $\begin{array}{l}\text { Business reputation, level of customer trust } \\
\text { and competitiveness of services }\end{array}$ & Number of countries of client companies $\left(x_{3}\right)$, quality of projects $\left(x_{4}\right)$ \\
\hline 3 & Management quality & $\begin{array}{l}\text { Degree of innovation of technologies used in the implementation of projects }\left(x_{5}\right) \text {, } \\
\text { quality of project management }\left(x_{6}\right)\end{array}$ \\
\hline 4 & $\begin{array}{l}\text { Quality of personnel management and } \\
\text { intellectual capital }\end{array}$ & $\begin{array}{l}\text { Personnel loyalty }\left(x_{7}\right) \text {, number of specialists }\left(x_{8}\right) \text {, number of technical specialists } \\
\left(x_{9}\right) \text {, number of newly employed specialists }\left(x_{10}\right)\end{array}$ \\
\hline
\end{tabular}

Thus, as a result of using the proposed filter of the system of indicators, from the initial information space of attributes, a system of 10 diagnostic indicators was selected (Table 1), which includes the most informative indicators of competitiveness of IT companies from the point of view of experts. The module for assessing and analyzing the competitiveness of IT companies includes the formation of homogeneous groups of IT companies in terms of competitiveness (Figure 1).

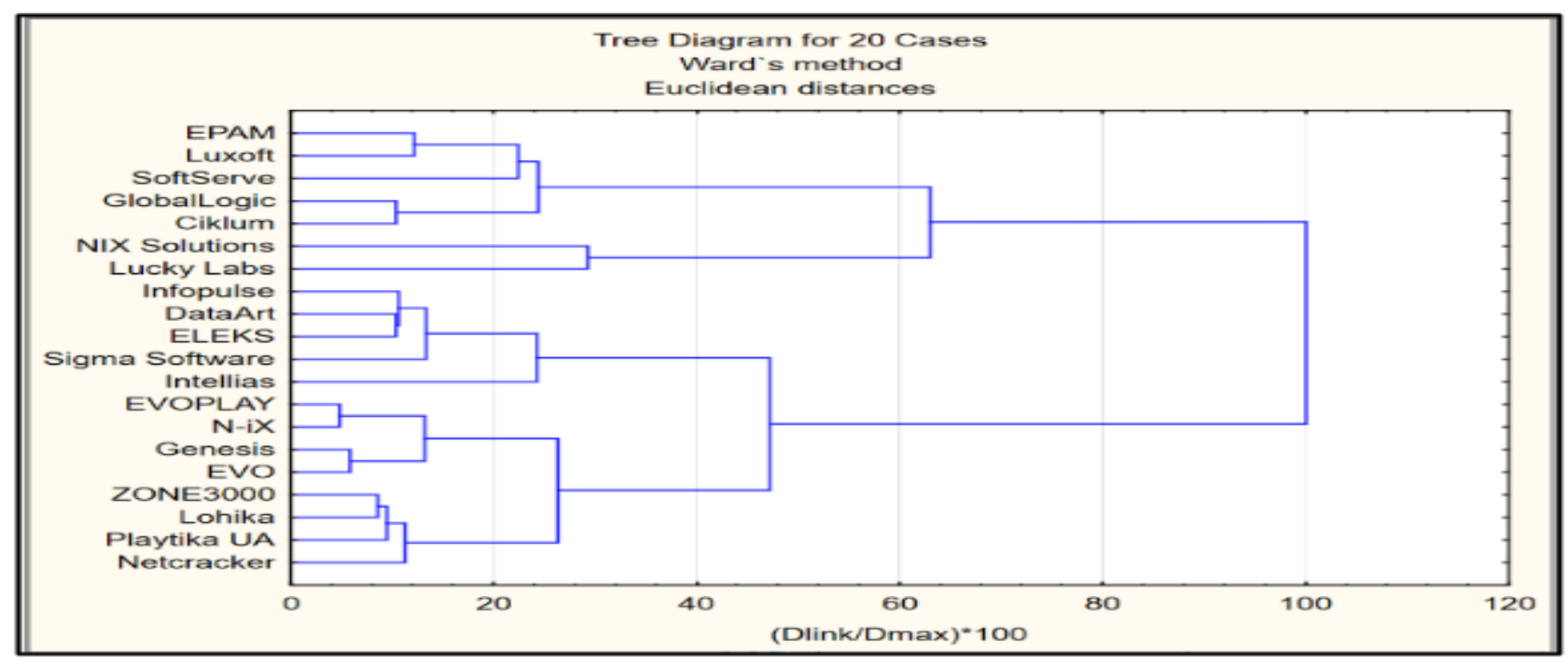

Fig. 1. Result of clustering based on standardized data using the Ward method as of 01.01.2016 Source: authors' research

The initial data for the clustering of IT companies are standardized values of the previously selected ten indicators $\left(x_{1}, x_{2}, x_{10}\right)$, which describe the state of the environment of a company. In the first step of this stage, a decision is taken on the number of clusters into which it is advisable to divide the original population. Visualization of the data structure is easy to obtain using hierarchical agglomerative cluster analysis. The results of the application of clustering using the Ward method based on standardized initial data as of 01.01.2016 are given in Figure 1. 
As can be seen from Figure 1, the population of companies under study is well divided into three groups. At the same time, we have one five-element cluster representing companies with a high level of competitiveness (EPAM, Luxoft, SoftServe, GlobalLogic, Ciklum), one two-element cluster representing companies with a low level of competitiveness (NIX Solutions, Lucky Labs) and the last cluster including all other companies with an average level of competitiveness.

Similar results were obtained for all other eight study periods from 01.07.2016 through 01.01.2020. The results are given in Annex E. Since the obvious division into three clusters using hierarchical methods was confirmed for all study periods, it is the division into three clusters that was used in k-means clustering. Summary results of kmeans clustering are given in Table 2.

Table 2. Clustering results

\begin{tabular}{|c|c|c|c|c|c|c|c|c|c|c|}
\hline No. & Name & 01.16 & 07.16 & 01.17 & 07.17 & 01.18 & 07.18 & 01.19 & 07.19 & 01.20 \\
\hline 1 & EPAM & 3 & 3 & 3 & 3 & 3 & 3 & 3 & 3 & 3 \\
\hline 2 & SoftServe & 3 & 3 & 3 & 3 & 3 & 3 & 3 & 3 & 3 \\
\hline 3 & GlobalLogic & 3 & 3 & 3 & 3 & 3 & 3 & 3 & 3 & 3 \\
\hline 4 & Luxoft & 3 & 3 & 3 & 3 & 3 & 3 & 3 & 3 & 3 \\
\hline 5 & Ciklum & 3 & 3 & 3 & 3 & 3 & 3 & 3 & 3 & 3 \\
\hline 6 & NIX Solutions & 1 & 1 & 1 & 1 & 1 & 1 & 1 & 1 & 1 \\
\hline 7 & Infopulse & 2 & 2 & 2 & 2 & 3 & 3 & 2 & 2 & 2 \\
\hline 8 & DataArt & 2 & 3 & 2 & 2 & 3 & 2 & 2 & 2 & 2 \\
\hline 9 & EVOPLAY & 2 & 2 & 2 & 2 & 2 & 2 & 2 & 2 & 2 \\
\hline 10 & Intellias & 2 & 2 & 2 & 2 & 2 & 2 & 2 & 2 & 2 \\
\hline 11 & ZONE3000 & 2 & 2 & 2 & 2 & 2 & 2 & 2 & 2 & 2 \\
\hline 12 & ELEKS & 2 & 2 & 2 & 2 & 2 & 2 & 2 & 2 & 2 \\
\hline 13 & Netcracker & 2 & 2 & 2 & 2 & 2 & 2 & 2 & 2 & 2 \\
\hline 14 & Genesis & 2 & 2 & 2 & 2 & 2 & 2 & 2 & 2 & 2 \\
\hline 15 & Sigma Software & 2 & 2 & 2 & 2 & 2 & 2 & 2 & 2 & 2 \\
\hline 16 & Lohika & 2 & 2 & 2 & 2 & 2 & 2 & 2 & 2 & 2 \\
\hline 17 & EVO & 2 & 2 & 2 & 2 & 2 & 2 & 2 & 2 & 2 \\
\hline 18 & $\mathrm{~N}-\mathrm{iX}$ & 2 & 2 & 2 & 2 & 2 & 2 & 2 & 2 & 2 \\
\hline 19 & Lucky Labs & 1 & 1 & 1 & 1 & 1 & 1 & 1 & 1 & 1 \\
\hline 20 & Playtika UA & 2 & 2 & 2 & 2 & 2 & 2 & 2 & 2 & 2 \\
\hline
\end{tabular}

The data in Table 2 can be interpreted as follows. Cluster 1 is a cluster of companies with a low level of competitiveness, cluster 2 - with a medium level of competitiveness, and cluster 3 - with a high level of competitiveness.

The composition of the first cluster did not change over time. Only two companies were permanently included in this group: NIX Solutions and Lucky Labs. The composition of cluster 3 was also unchanged for three periods: 01.01.2016, from 01.01.2017 through 01.07.2017 and from 01.01.2019 through 01.01.2020. As of January 1, 2018, two more companies joined the five companies of this group (ERAM, Luxoft, SoftSeive, GlobalLogic, Ciklum): Infopulse and DataArt, as of 01.07.2016 - only DataArt, as of 01.07.2018 - only Infopulse. Similar results were obtained when using the Ward method, which indicates the stability of the obtained clustering results. 
The average values of the initial indicators for each of the clusters as of 01.01.2016 are given in Figure 2 .

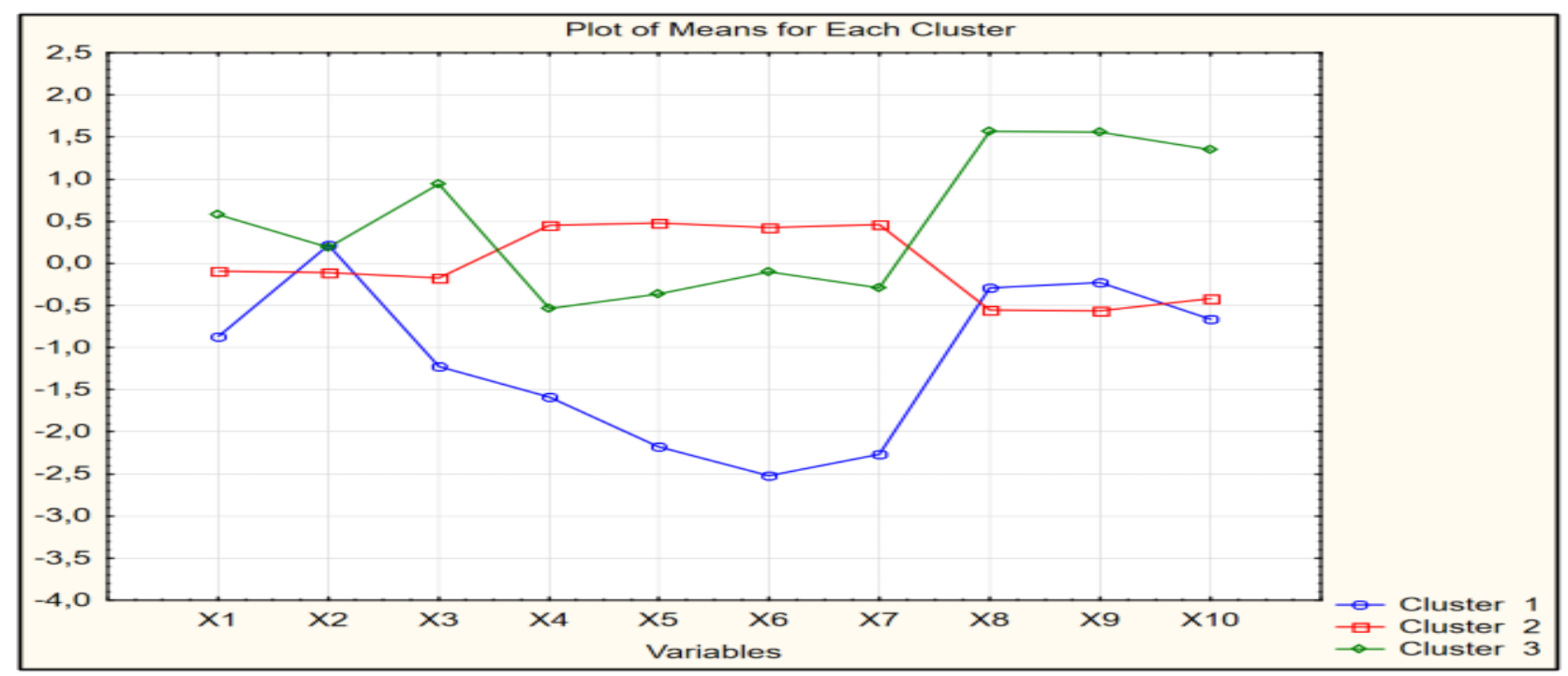

Fig. 2. Average values of the initial indicators for each of the clusters as of 01.01 .2016 Source: authors' research

The distribution of means of indicators by clusters remains practically unchanged for all nine study periods. This gives reason to talk about the stability of the obtained results. As can be seen from Figure 2, the group of companies with a low level of $\mathrm{KC}$ (cluster 1 ) has the lowest values for the following indicators: $x_{1}$ - number of structural divisions of a company; $x_{3}$ - number of countries of client companies; $x_{4}$ - quality of projects; $x_{5}$ - level of innovation of technologies used in the implementation of projects; $x_{6}$ - quality of project management; $x_{7}$ - personnel loyalty; $x_{10}$ - number of newly employed specialists. That is, these companies lag behind by all four general factors: market activity, business reputation, quality of management and quality of personnel management.

The group of companies with a high level of $\mathrm{KC}$ (cluster 3 ) has the highest values for the following indicators: $x_{1}$ - number of structural divisions of a company; $x_{2}$ - number of industry solutions (areas of activity); $x_{3}$ number of countries of client companies; $x_{8}$ - number of specialists; $x_{9}$ - number of technical specialists; $x_{10}$ - number of newly employed specialists. That is, these companies occupy leading positions in the IT market of Ukraine due to high market activity, fairly high business reputation and competitiveness of services, as well as high quality of personnel management and intellectual capital.

The group of companies with an average level of $\mathrm{KC}$ (cluster 2) is characterized by the highest level of indicators $x_{4}$ - quality of projects; $x_{5}$ - level of innovation of technologies used in the implementation of projects; $x_{6}$ quality of project management; $x_{7}$ - personnel loyalty, which indicates the high potential of KC development for these companies.

We consider the results of the construction of a fuzzy membership function of the competitiveness class of the Mamdani algorithm. The input data for construction of the model are the values of the initial indicators, which form the local integrated assessments of competitiveness and the results of clustering presented in Table 2. Cluster 
1 contains two companies (numbers 6 and 19) with a low level of competitiveness, cluster 2 - companies with a high level of KC (numbers 1-5), and cluster 3 - companies with an average level of competitiveness (numbers 7-18 and 20). MATLAB APP is used to construct these membership functions.

Table 3 shows the values obtained for companies and reflects the actual cluster distribution and the distribution found using the Mamdani algorithm, as of 01.01.2020.

Table 3. Final values for companies and distribution by clusters as of 01.01 .2020

\begin{tabular}{|c|c|c|c|c|}
\hline No. & Company & $\begin{array}{l}\text { Membership } \\
\text { value }\end{array}$ & Original cluster & Mamdani algorithm cluster \\
\hline \multicolumn{5}{|c|}{ Cluster 1} \\
\hline 1 & NIX Solutions & 0.0264 & 17 & 1 \\
\hline 2 & Lucky Labs & 0.0264 & 1 & 1 \\
\hline \multicolumn{5}{|c|}{ Cluster 2} \\
\hline 3 & EPAM & 0.282 & 2 & 2 \\
\hline 4 & SoftServe & 0.225 & 2 & 2 \\
\hline 5 & GlobalLogic & 0.225 & 2 & 2 \\
\hline 6 & Luxoft & 0.304 & 2 & 2 \\
\hline 7 & Ciklum & 0.5 & 2 & 3 \\
\hline \multicolumn{5}{|c|}{ Cluster 3} \\
\hline 8 & Infopulse & 0.752 & 3 & 3 \\
\hline 9 & DataArt & 0.752 & 3 & 3 \\
\hline 10 & EVOPLAY & 0.722 & 3 & 3 \\
\hline 11 & Intellias & 0.763 & 3 & 3 \\
\hline 12 & ZONE3000 & 0.703 & 3 & 3 \\
\hline 13 & ELEKS & 0.763 & 3 & 3 \\
\hline 14 & Netcracker & 0.500 & 3 & 3 \\
\hline 15 & Genesis & 0.813 & 3 & 3 \\
\hline 16 & Sigma Software & 0.784 & 3 & 3 \\
\hline 17 & Lohika & 0.752 & 3 & 3 \\
\hline 18 & EVO & 0.701 & 3 & 3 \\
\hline 19 & $\mathrm{~N}-\mathrm{iX}$ & 0.784 & 3 & 3 \\
\hline 20 & Playtika UA & 0.774 & 3 & 3 \\
\hline
\end{tabular}

As can be seen from Table 3, the results of clustering coincide by $95 \%$. Ciklum tends to migrate to a cluster of companies with an average level of competitiveness. This is due to a significant slowdown in the growth rate of the company (by $25 \%$ over the past five years). The implementation of this model was carried out using EViews APP. Among the three types of models: a regular model based on panel data, a model with fixed effects and a model with random effects, the model with fixed effects has the highest quality. The values of the fixed effect are given in Figure 3. 


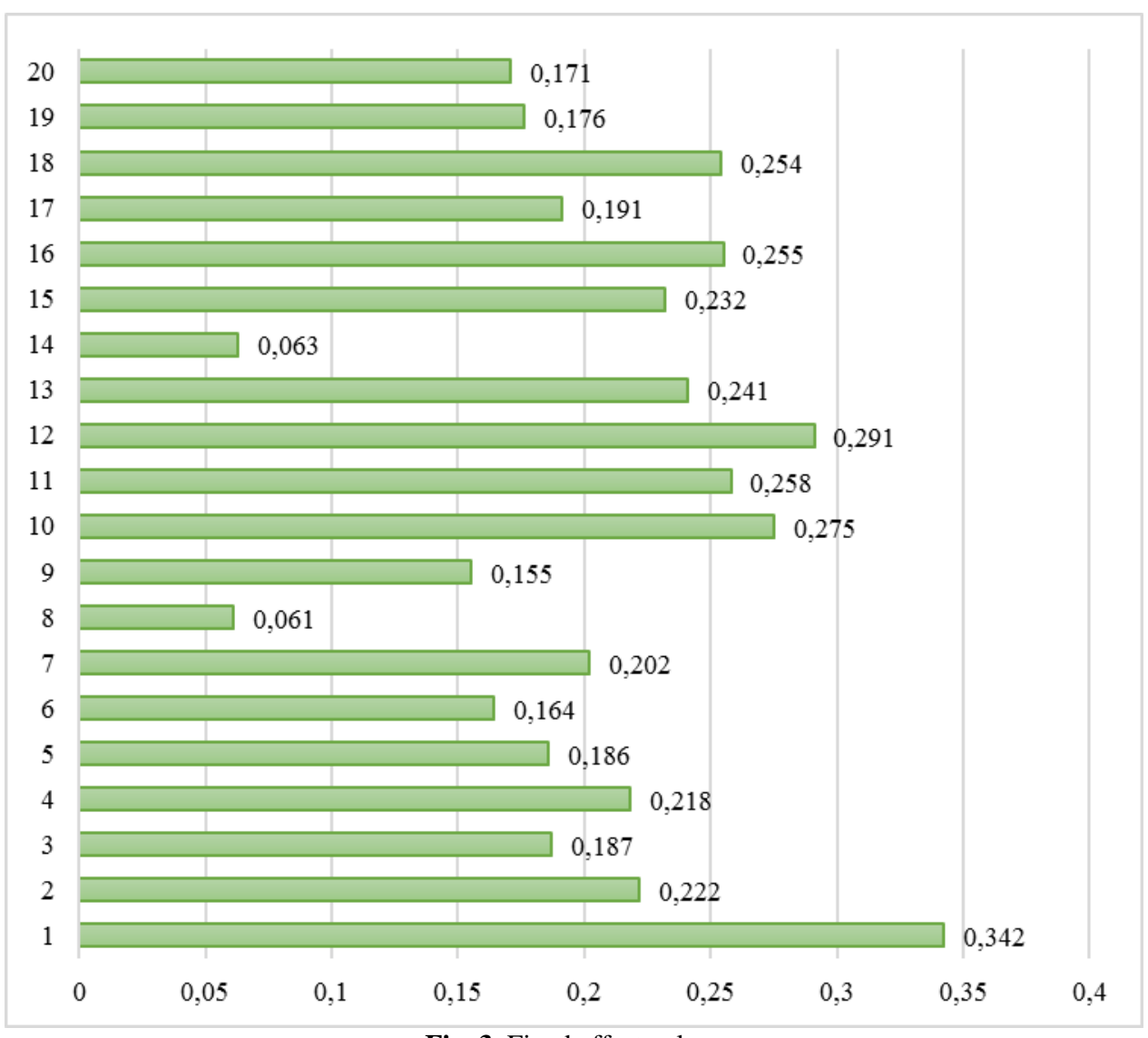

Fig. 3. Fixed effect values Source: authors' research

As can be seen from Figure 3, a model with a fixed effect is adequate by the values of the coefficient of determination and the adjusted coefficient of determination ( 0.9881 and 0.9864 , respectively). They are close to 1 , which indicates that more than $98 \%$ of the variability of the dependent variable is explained by the built model. We can also note the high value of Student's t-statistic (6.18), which indicates the statistical significance of the influence of the lag variable. The value of Durbin-Watson statistic is close to 2 (1.959) and indicates the absence of autocorrelation of model errors.

When using Fisher's test to check the statistical significance of the parameters of the intersection (location) in the model, the null hypothesis was rejected and the H1 hypothesis was accepted, $\mu_{i} \neq \mu_{j}$ which corresponds to the model with fixed effects, as the calculated value of $\mathrm{F}=3.798$ exceeds the tabular one of 1.65 . According to Breusch-Pagan test, the calculated value of LM statistics is equal to 6.357, which exceeds the value of 3.84 . Therefore, we can conclude that we should prefer a model with a random effect. According to Hausman test, the calculated value of $\mathrm{H}$ statistics is equal to 45.153, which significantly exceeds the tabular value of Pearson's criterion equal to 3.84 , so we accept the $\mathrm{H} 1$ hypothesis that the difference between the values of models with random and fixed effects is significant, and the values of a model with fixed effects are sound, i.e., the choice is made in favor of a model with a fixed effect.

Thus, at the last seventh stage of the proposed methodical approach to forecast the level of KC of IT companies a model with fixed effects is used. The forecast values of the integrated assessment of the level of competitiveness of IT companies obtained using this model are given in Table 4. 
ENTREPRENEURSHIP AND SUSTAINABILITY ISSUES

ISSN 2345-0282 (online) http://jssidoi.org/jesi/

2021 Volume 8 Number 4 (June)

http://doi.org/10.9770/jesi.2021.8.4(43)

Table 4. Forecast values obtained using a model with fixed effects

\begin{tabular}{|c|c|c|c|c|c|c|c|}
\hline No. & Company & 07.01 .20 & 01.01 .21 & 01.07 .21 & 01.01 .22 & 01.07 .22 & 01.01 .23 \\
\hline 1 & EPAM & 0.6663 & 0.6613 & 0.6589 & 0.6577 & 0.6572 & 0.6569 \\
\hline 2 & SoftServe & 0.5486 & 0.5539 & 0.5564 & 0.5576 & 0.5582 & 0.5585 \\
\hline 3 & GlobalLogic & 0.2961 & 0.2043 & 0.1604 & 0.1394 & 0.1293 & 0.1245 \\
\hline 4 & Luxoft & 0.4872 & 0.4651 & 0.4545 & 0.4495 & 0.4471 & 0.4459 \\
\hline 5 & Ciklum & 0.4575 & 0.4737 & 0.4814 & 0.4851 & 0.4869 & 0.4877 \\
\hline 6 & NIX Solutions & 0.2516 & 0.3115 & 0.3401 & 0.3538 & 0.3604 & 0.3635 \\
\hline 7 & Infopulse & 0.4549 & 0.4715 & 0.4794 & 0.4832 & 0.4851 & 0.4859 \\
\hline 8 & DataArt & 0.3986 & 0.3644 & 0.3480 & 0.3402 & 0.3364 & 0.3347 \\
\hline 9 & EVOPLAY & 0.3510 & 0.3388 & 0.3330 & 0.3302 & 0.3289 & 0.3283 \\
\hline 10 & Intellias & 0.4553 & 0.4404 & 0.4333 & 0.4299 & 0.4283 & 0.4275 \\
\hline 11 & ZONE3000 & 0.3471 & 0.3533 & 0.3562 & 0.3577 & 0.3583 & 0.3587 \\
\hline 12 & ELEKS & 0.4175 & 0.4175 & 0.4174 & 0.4174 & 0.4174 & 0.4174 \\
\hline 13 & Netcracker & 0.3388 & 0.3480 & 0.3523 & 0.3544 & 0.3554 & 0.3559 \\
\hline 14 & Genesis & 0.3400 & 0.3269 & 0.3206 & 0.3176 & 0.3162 & 0.3155 \\
\hline 15 & Sigma Software & 0.3985 & 0.3926 & 0.3897 & 0.3884 & 0.3877 & 0.3874 \\
\hline 16 & Lohika & 0.2326 & 0.1728 & 0.1442 & 0.1305 & 0.1239 & 0.1208 \\
\hline 17 & EVO & 0.3029 & 0.2996 & 0.2980 & 0.2972 & 0.2969 & 0.2967 \\
\hline 18 & $\mathrm{~N}-\mathrm{iX}$ & 0.4578 & 0.4942 & 0.5115 & 0.5199 & 0.5238 & 0.5258 \\
\hline 19 & Lucky Labs & 0.3118 & 0.4073 & 0.4531 & 0.4750 & 0.4855 & 0.4905 \\
\hline 20 & Playtika UA & 0.3823 & 0.4243 & 0.4444 & 0.540 & 0.4586 & 0.4608 \\
\hline
\end{tabular}

As can be seen from Table 4, in the medium term, companies such as EPAM, SoftServe, Luxoft and Ciklum will maintain their leading positions in the IT industry. However, EPAM and Luxoft are characterized by negative dynamics of changes in the integrated indicator of the level of competitiveness, which indicates the need to adapt the strategy of managing the competitiveness of these companies. The highest rates of development are demonstrated by Lucky Labs, NIX Solutions, and Playtika UA. Besides, we should pay attention to Infopulse, which tends to migrate to the cluster of companies with a high level of development (Table 2) and demonstrates the positive dynamics of changes in the integrated indicator in the forecast period (Table 4). However, the growth rate of the company is not sufficient to ensure a stable competitive position in the cluster of leading companies.

Thus, the conducted studies allow us to draw the following conclusions:

- The use of the proposed algorithm of the filter of the system of indicators of KC of IT-companies based on the methods of expert analysis allowed to significantly reduce the dimensionality of the original information space of attributes without losing significant information. It is based on the input system of indicators, which includes 10 most informative variables for monitoring and assessment of the level of $\mathrm{KC}$ of IT-companies;

- A system of general and local (by individual components) integrated indicators of KC of IT-companies was developed, which demonstrated a significant differentiation of IT companies by competitiveness (the coefficient of variation of the study population is more than $30 \%$ ). The companies, which were characterized by the highest level of competitiveness during the study period, include EPAM, Luxoft and SoftServe;

- Clusters of companies homogeneous by the level of competitiveness were created. For the companies differentiated management strategies can be developed. And companies were selected, which tend to migrate to a 


\section{ENTREPRENEURSHIP AND SUSTAINABILITY ISSUES}

ISSN 2345-0282 (online) http://jssidoi.org/jesi/

2021 Volume 8 Number 4 (June)

http://doi.org/10.9770/jesi.2021.8.4(43)

group of companies with higher or lower competitive positions. It should be noted that there is a small gap between the levels of competitiveness of leading companies and the companies of the "second cluster", which indicates a high intensity of competition in the IT sector;

- The models of panel data on the level of competitiveness of IT companies were developed. The obtained results allowed to identify ERAM and Luxoft as the objects for further studies. The forecast dynamics of their development is characterized by negative trends of change of level KC. Although these companies remain in the cluster of companies with a high level of $\mathrm{KC}$, their position in the cluster is worsening. The state of Infopulse, which tends to migrate to the cluster of companies with a high level of development and demonstrates the positive dynamics of changes in the integrated indicator in the forecast period, will be considered in more detail. However, the growth rate of the company is not sufficient to form a sustainable trajectory of development and move into the cluster of leading companies.

\section{Discussion}

The largest risks for Ukrainian SMEs in the conditions of quarantine are: shutdown, liquidity deficit, reduction of consumer demand, disruption of value and supply chains, loss of domestic market, uncertainty in foreign markets, as well as unpreparedness of the regulatory environment of Ukraine for stimulation of the dynamic development of business potential. The implementation of business potential depends on the rapid modernization and adaptation of state support policy. Strengthening efforts of legislative and executive bodies will reduce risks to SME development.

State policy reformatting should include:

1) Implementation of an anti-crisis action plan to support entrepreneurship in the conditions of quarantine measures and in the period of economic recovery (Danylyshyn (2020));

2) Reduction of the regulatory burden and development of a package of measures focused on preserving markets for SMEs in the conditions of restrictions (Nadiia \& Anna (2021));

3) Development of measures to prevent corruption abuses and discrimination of economic entities during the quarantine (Åslund (2020));

4) Accelerated simplification of tax administration (Rozanova et. al (2020));

5) Improved access to financing (Kyrychko et. al (2020));

6) Creation of export stimulation infrastructure (Kyrylov et. al (2020));

7) Extension of digital transformations, expansion of digital tools for remote financial and economic operations (Ashraf (2020)).

\section{Conclusions}

Considering the importance of improving the business climate for the implementation of business potential in an economic crisis, it is necessary to further study the existing obstacles to the development of entrepreneurship in Ukraine in order to identify priorities for overcoming them for stimulation of sustainable economic development.

The expediency of applying the level of development method to build an integrated assessment of the level of competitiveness of IT companies is substantiated. Integrated assessments were built, both for the whole system of indicators and for individual areas, which allowed to identify "critical" subsystems, the growth of threats in which leads to the loss of current market positions of IT companies.

Based on hierarchical agglomerative and iterative methods of cluster analysis, clusters of companies homogeneous in terms of competitiveness were identified. Comparison of the results of ranking of objects based on the level of development method and cluster analysis allowed to determine the intensity of competition in the 


\section{ENTREPRENEURSHIP AND SUSTAINABILITY ISSUES}

ISSN 2345-0282 (online) http://jssidoi.org/jesi/

2021 Volume 8 Number 4 (June)

http://doi.org/10.9770/jesi.2021.8.4(43)

IT industry, the gap in the levels of competitiveness of companies with high and low competitive positions, to determine the propensity of enterprises to migrate from cluster to cluster. With the help of the methods of fuzzy logic theory, models of competitiveness cluster recognition were developed, which confirmed the stability of the results of cluster analysis and were used to identify the competitiveness cluster in the forecast period in the framework of proactive management.

The models of panel data on KC of IT companies are built, on the basis of which the exploratory spatial-dynamic forecast of $\mathrm{KC}$ level is developed taking into account both dynamic changes in the level of both a company itself and positions of competing companies. Comparison of the current and forecast level of competitiveness allowed to assess the stability of competitive positions of companies, to identify IT companies, for which it is advisable to develop proactive strategies aimed at reversing the negative trends, which are being formed based on forecast data according to the adopted strategy of $\mathrm{KC}$ management.

\section{References}

$60 \%$ of Ukrainians have suffered financial losses due to the coronavirus pandemic (2020). Retrieved from: https://sapiens.com.ua/ua/publication-single-page?id=114

Ashraf, B. N. (2020). Stock markets' reaction to COVID-19: Cases or fatalities?. Research in International Business and Finance, 54, 101249. Retrieved from: https://www.sciencedirect.com/science/article/abs/pii/S0275531920304141

Åslund, A. (2020). Responses to the COVID-19 crisis in Russia, Ukraine, and Belarus. Eurasian Geography and Economics, 61(4-5), 532545. Retrieved from: https://www.tandfonline.com/doi/full/10.1080/15387216.2020.1778499

Battaglia, D., Paolucci, E., \& Ughetto, E. (2021). The fast response of academic spinoffs to unexpected societal and economic challenges. Lessons from the COVID-19 pandemic crisis. R\&D Management, 51(2), 169-182. Retrieved from: https://onlinelibrary.wiley.com/doi/full/10.1111/radm.12444

Danylyshyn, B. (2020). The peculiarities of economic crisis due to COVID-19 pandemic in a developing country: case of Ukraine. Problems and Perspectives in Management, 18(2), $13-22 . \quad$ Retrieved https://pdfs.semanticscholar.org/5686/2163e6778755ab79fe071e939cb1da712c3f.pdf

Essential Information (2021). NASSCOM. Retrieved from: https://nasscom.in/

IMF Digest of the COVID-19 Response Policy (2021). Retrieved from: https://www.imf.org/en/Topics/imf-and-covid19/Policy-Responses$\underline{\text { to-COVID-19 }}$

Helping companies innovate and grow internationally (2021). Retrieved from: https://een.ec.europa.eu/

Ketchen Jr, D. J., \& Craighead, C. W. (2020). Research at the intersection of entrepreneurship, supply chain management, and strategic management: Opportunities highlighted by COVID-19. Journal of Management, 46(8), 1330-1341. Retrieved from: https://journals.sagepub.com/doi/full/10.1177/0149206320945028

Kyrychko, Y. N., Blyuss, K. B., \& Brovchenko, I. (2020). Mathematical modelling of the dynamics and containment of COVID-19 in Ukraine. Scientific reports, 10(1), 1-11. Retrieved from: https://www.nature.com/articles/s41598-020-76710-1

Kyrylov, Y., Hranovska, V., Boiko, V., Kwilinski, A., \& Boiko, L. (2020). International Tourism Development in the Context of Increasing Globalization Risks: On the Example of Ukraine's Integration into the Global Tourism Industry. Journal of Risk and Financial Management, 13(12), 303. Retrieved from: https://www.mdpi.com/1911-8074/13/12/303

Leach, M., MacGregor, H., Scoones, I., \& Wilkinson, A. (2021). Post-pandemic transformations: How and why COVID-19 requires us to rethink development. World Development, $138, \quad 105233 . \quad$ Retrieved https://www.sciencedirect.com/science/article/pii/S0305750X20303600 


\section{ENTREPRENEURSHIP AND SUSTAINABILITY ISSUES}

ISSN 2345-0282 (online) http://jssidoi.org/jesi/

2021 Volume 8 Number 4 (June)

http://doi.org/10.9770/jesi.2021.8.4(43)

Maritz, A., Perenyi, A., de Waal, G., \& Buck, C. (2020). Entrepreneurship as the unsung hero during the current COVID-19 economic crisis: Australian perspectives. Sustainability, 12(11), 4612. Retrieved from: https://www.mdpi.com/2071-1050/12/11/4612

Nadiia, P. R., \& Anna, M. S. (2021). Social Responsibility of Ukrainian Business in the Conditions of the Covid-19 Pandemic: Foreign and Domestic Practice. The Importance of New Technologies and Entrepreneurship in Business Development: In The Context of Economic Diversity in Developing Countries, 194, 1850. Retrieved from: https://www.ncbi.nlm.nih.gov/pmc/articles/PMC7972443/

National accounts (GDP) (2020). State Statistics Service of Ukraine. Retrieved http://ukrstat.gov.ua/imf/arhiv/nr/nr_u.htm

National Economic Strategy-2030 (2021). Ministry of Economic Development, Trade and Agriculture. Retrieved from: https://www.me.gov.ua/News/Detail?lang=uk-UA\&id=18a8406c-164a-4104-a02fcef3010b8b8c\&title=IgorPetrashkoRozpovivProRetseptVidnovlenniaEkonomiki

Operational information on expenditures to combat COVID-19 (2021). Retrieved from: https://mof.gov.ua/uk/data_and_analytics-433

Rozanova, J., Shenoi, S., Zaviryukha, I., Zeziulin, O., Kiriazova, T., Rich, K., ... \& Yariy, V. (2020). Social support is key to retention in care during Covid-19 pandemic among older people with hiv and substance use disorders in Ukraine. Substance use \& misuse, 55(11), 1902-1904. Retrieved from: https://www.tandfonline.com/doi/full/10.1080/10826084.2020.1791183

S\&P500 (2020). Retrieved from: https://ru.investing.com/indices/us-spx-500

SRSU will continue to work on elimination of legal, administrative, economic and organizational barriers to business (2020). State Regulatory Service of Ukraine. Retrieved from: http://www.drs.gov.ua/press-room/drs-dali-pratsyuvatyme-nad-usunennyam-pravovyhadministratyvnyh-ekonomichnyh-ta-organizatsijnyh-pereshkod-dlya-biznesu/?print_page=true

USAID Competitive Economy of Ukraine (CEU) receives concepts of grant projects from business associations (APS) (2021). Retrieved from: https://www.prostir.ua/?grants=prohrama-usaid-konkurentospromozhna-ekonomika-ukrajiny-keu-pryjmaje-kontseptsiji-hrantovyhproektiv-vid-biznes-asotsiatsij-rpz-2019-002 
Vladislav FEDORENKO, Doctor of Law, Professor, Director of the Research Center for Forensic Examination on Intellectual Property of the Ministry of Justice of Ukraine

ORCID ID: orcid.org/0000-0001-5902-1226

Natalia FILIPENKO, PhD in Law, Associate Professor, Associate Professor of Law, Zhukovsky National Aerospace University "Kharkiv Aviation Institute"

ORCID ID: orcid.org/0000-0001-9469-3650

Inesa SHUMILO, Candidate of Juridical Sciences, Associate Professor, International Private Law and Comparative Law Department Yaroslav Mudryi National Law University

ORCID ID: orcid.org/0000-0002-2123-7272

Volodymyr NESTEROVYCH, Doctor of Law, Associate Professor, Head of the Department of State-Legal Disciplines, Lugansk State University of Internal Affairs named after E.O. Didorenko

ORCID ID: orcid.org/0000-0003-2614-0426

Svitlana NISCHYMNA, Doctor of Sciences (Law), Professor, Head of the Department of Administrative, Civil and Commercial Law and Process, Academy of the State Penitentiary Service

ORCID ID: orcid.org/0000-0001-7424-7888 